\title{
PENGARUH APLIKASI KOMBINASI NAA (Naphtaleneacetic Acid) Dan IBA (Indole Butyric Acid) TERHADAP PENGAKARAN SETEK LADA (Piper nigrum Linn) VARIETAS NATAR 1
}

\author{
Dita Dani Artha, Yusnita \& Sugiatno
}

Jurusan Agroteknologi, Fakultas Pertanian Universitas Lampung

Jl. Prof. Dr. Soemantri Brodjonegoro no. 1 Bandar Lampung 35145

\begin{abstract}
ABSTRAK
Lada merupakan salah satu tanaman penting di Indonesia. Setek merupakan perbanyakan tanaman yang efektif dan efisien dalam budidaya tanaman lada. Salah satu kendala dalam perbanyakan tanaman dengan setek yaitu sulitnya mendapatkan bahan tanaman dalam jumlah yang banyak dan berkualitas. Salah satu cara untuk mendapatkan bahan tanaman dalam jumlah yang banyak yaitu dengan menggunakan setek lada $6-8$ buku. Pemberian auksin pada setek lada dapat meningkatkan pembentukan akar. Penelitian ini dilakukan untuk mengetahui pengaruh aplikasi campuran auksin NAA dan IBA pada konsentrasi berbeda terhadap pengakaran setek lada, mengetahui pengaruh peningkatan konsentrasi campuran NAA dan IBA terhadap pengakaran setek lada, dan menentukan konsentrasi campuran auksin NAA dan IBA yang optimum untuk pembentukan akar setek lada. Penelitian ini menggunakan Rancangan Acak Lengkap (RAL) dengan tujuh perlakuan. Perlakuan yang dicobakan adalah kontrol (tanpa auksin), 500 ppm (250 NAA +250 IBA), 1000 ppm (500 NAA +500 IBA), 2000 ppm (1000 NAA+1000 IBA), 4000 ppm (2000 NAA +2000 IBA), 6000 ppm (3000 NAA +3000 IBA), 8000 ppm (4000 NAA+4000 IBA), masing-masing perlakuan diulang tiga kali. Auksin yang digunakan dalam bentuk powder mixture. Setiap satuan percobaan terdiri atas sepuluh setek batang. Data yang dianalisis dengan sidik ragam (ANOVA). Perbedaan nilai tengah masing-masing perlakuan diuji dengan uji beda nyata terkecil (BNT) pada taraf nyata 5\%. Hasil percobaan menunjukkan bahwa pemberian campuran NAA dan IBA mulai 500 ppm hingga 8000 ppm secara signifikan meningkatkan jumlah akar, dengan jumlah akar terbanyak terdapat pada perlakuan $1000 \mathrm{ppm}$. Pemberian campuran NAA dan IBA mulai dari 500 ppm hingga $8000 \mathrm{ppm}$ secara signifikan meningkatkan panjang akar primer dan bobot segar akar dengan akar terpanjang dan bobot akar tertinggi terdapat pada perlakuan 6000 ppm. Berdasarkan morfologi akar, panjang akar, dan bobot akar, pemberian campuran NAA dan IBA 6000 ppm merupakan perlakuan terbaik untuk merangsang pembentukan akar pada setek lada varietas Natar 1. Tanpa auksin setek lada tidak dapat membentuk akar di dasar setek. Aplikasi campuran auksin NAA dan IBA mulai dari 500 ppm hingga 8000 ppm merangsang pembentukan akar pada dasar setek dengan persentase tertinggi didapat pada perlakuan campuran NAA dan IBA $8000 \mathrm{ppm}$.
\end{abstract}

Kata Kunci : IBA (Indole Butyric Acid), NAA (Naphtaleneacetic Acid), setek lada 6-8 buku.

\section{PENDAHULUAN}

Lada (Piper nigrum Linn.) merupakan tanaman rempah-rempah yang memiliki peran penting dalam meningkatkan perekonomian Indonesia. Perbanyakan lada dapat dilakukan secara vegetatif dan generatif. Perbanyakan tanaman lada dengan setek merupakan perbanyakan tanaman yang efektif dan efisien dalam budidaya tanaman lada. Perbanyakan lada dengan setek lebih menguntungkan karena menghasilkan populasi tanaman yang homogen dan memiliki sifat yang sama dengan induknya (Balai Informasi Pertanian Irian Jaya, 1994).

Salah satu kendala dalam perbanyakan tanaman dengan setek yaitu sulitnya mendapatkan bahan tanaman dalam jumlah yang banyak dan berkualitas. Setek pendek dua buku lebih efektif dan efisien bila dibandingkan dengan setek panjang. Keuntungan perbanyakan setek lada dua buku antara lain dapat menyediakan bibit dalam jumlah yang banyak dalam jangka waktu yang relatif cepat sehingga menghemat penggunaan bahan tanaman. Penggunaan setek dua buku hanya memerlukan sedikit penyulaman, memiliki rata-rata cabang generatif lebih banyak sehingga dapat berbunga lebih cepat (Balai Penelitian Tanaman Rempah dan Obat, 1996).

Salah satu faktor kunci yang berpengaruh pada keberhasilan setek adalah terbentuknya akar adventif pada setek. Proses pembentukan akar dipengaruhi oleh dua faktor yaitu faktor dari dalam dan faktor dari luar. 
Faktor luar meliputi suhu, media pengakaran, kelembaban udara, dan intensitas cahaya. Faktor dari dalam yang berperan dalam pembentukan akar yaitu faktor genetik dan hormonal. Faktor hormonal di antaranya adalah tersedianya auksin endogen dalam jaringan tanaman (Hartmann et al., 2011 ). Pop et al. (2011) menjelaskan bahwa proses pembentukan akar adventif dipengaruhi oleh dua faktor yaitu lingkungan seperti suhu dan cahaya dan faktor dalam seperti hormon. Jika ketersediaan auksin endogen dalam bahan setek terbatas, maka pemberian auksin dari luar diperlukan untuk merangsang terbentuknya akar. Pemberian IBA 3000 ppm pada setek Vittelaria paradoxa dapat meningkatkan jumlah akar (Akakpo et al., 2014).

Menurut Memon et al. (2013) pemberian NAA pada setek bougenvil terbukti dapat merangsang terbentuknya akar. Paul dan Auditi (2009) juga menjelaskan bahwa pemberian baik NAA maupun IBA dapat merangsang pembentukan akar. Menurut Hartmann et al. (2011) penggunaan kombinasi auksin dengan konsentrasi yang sama beberapa zat pengatur tumbuh mungkin lebih efektif bila dibandingkan dengan pengaturan zat pengatur tumbuh secara tunggal. Kombinasi NAA dan IBA dengan konsentrasi yang sama bila diaplikasikan pada beberapa spesies tanaman dilaporkan lebih efektif meningkatkan jumlah akar bila dibandingkan penggunaan auksin secara tunggal. Tujuan penelitian ini adalah untuk mengetahui pengaruh aplikasi campuran auksin NAA dan IBA pada konsentrasi berbeda terhadap pengakaran setek lada, mengetahui pengaruh peningkatan konsentrasi campuran NAA dan IBA terhadap pengakaran setek lada, dan menentukan konsentrasi campuran auksin NAA dan IBA yang optimum untuk pembentukan akar setek lada.

\section{BAHAN DAN METODE}

Penelitian ini dilaksanakan di rumah kaca dan Laboratorium Ilmu Tanaman Fakultas Pertanian Universitas Lampung dari bulan September 2013 sampai November 2013. Bahan yang digunakan adalah powder mixture kombinasi auksin NAA dan IBA 500 ppm (250 NAA+250 IBA), 1000 ppm (500 NAA+500 IBA), 2000 ppm (1000 NAA+1000 IBA), 4000 ppm (2000 NAA+2000 IBA), 6000 ppm (3000 NAA+3000 IBA), 8000 ppm (4000 NAA+4000 IBA), setek lada, dan pasir kali. Alat yang digunakan adalah timbangan elektrik, gelas beaker, paranet, mangkuk plastik volume $400 \mathrm{ml}$.

Penelitian ini dilakukan menggunakan rancangan acak lengkap dengan 7 perlakuan campuran auksin NAA dan IBA dengan perbandingan yang sama yaitu kontrol atau 0 ppm, 500 ppm, 1000 ppm, 2000 ppm, 4000 ppm, 6000 ppm, dan 8000 ppm. Setiap perlakuan diulang tiga kali dan setiap unit percobaan terdiri dari 10 setek. Data yang diperoleh dianalisis dengan menggunakan analisis ragam (Anova). Perbedaan nilai tengah perlakuan ditentukan dengan uji BNT pada taraf nyata $5 \%$.

Bahan tanaman diolesi dengan bubuk campuran auksin pada pangkal batang, kemudian ditanam di media pasir yang telah disediakan. Setek diletakkan di rumah kaca dan disungkup dengan paranet untuk menghindari sinar matahari secara langsung. Perawatan tanaman dilakukan dengan cara menyiram tanaman setiap hari pada sore hari. Pengamatan dilakukan setelah setek berumur 2 bulan. Variabel yang diamati adalah persentase setek tumbuh, persentase setek berakar, jumlah akar primer, panjang akar primer, persentase setek bertunas, bobot segar akar, dan penampilan visual akar.

\section{HASIL DAN PEMBAHASAN}

Hasil penelitian menunjukkan bahwa aplikasi campuran NAA dan IBA berpengaruh terhadap jumlah akar, panjang akar, dan bobot segar akar. Rekapitulasi hasil analisis ragam pengaruh pemberian campuran NAA dan IBA terhadap setek lada 2 bulan setelah penyetekan dapat dilihat pada Tabel 1. Hasil pengamatan menunjukkan bahwa persentase setek yang hidup setelah 2 bulan berkisar antara $46,7 \%$ yaitu pada perlakuan campuran NAA dan IBA 6000 ppm hingga 83,3\% yaitu pada perlakuan campuran NAA dan IBA 500 ppm. Persentase setek hidup dapat dilihat pada Gambar 1a.

Hasil pengamatan persentase setek berakar setek lada setelah 2 bulan menunjukkan bahwa persentase setek berakar lada berkisar antar 30\% hingga $40 \%$ (Gambar 1b). Hal ini kemungkinan karena penelitian ini dilakukan pada kondisi yang kurang optimum. Bahan

Tabel 1. Rekapitulasi hasil analisis ragam pengaruh pemberian campuran NAA dan IBA terhadap setek lada 2 bulan setelah penyetekan.

\begin{tabular}{clc}
\hline No & Variabel penga matan & Signifikansi \\
\hline 1 & Persentase setek hidup & tn \\
2 & Persentase setek berakar & tn \\
3 & Persentase setek bertunas & tn \\
4 & Jumlah ak ar primer & $*$ \\
5 & Panja ng akar primer & $*$ \\
6 & Bobot segar akar & $*$ \\
\hline
\end{tabular}

Keterangan $: \operatorname{tn}=$ tidak nyata, ${ }^{*}=$ nyata pada taraf $5 \%$. 


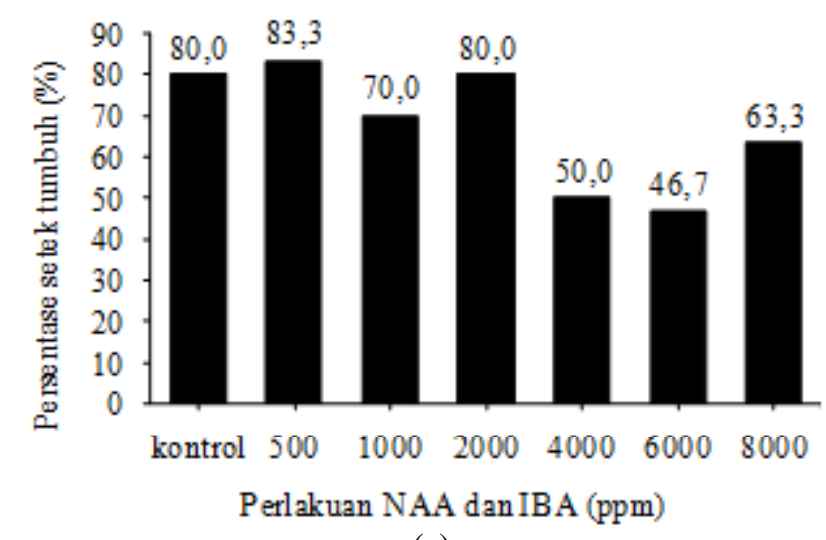

(a)

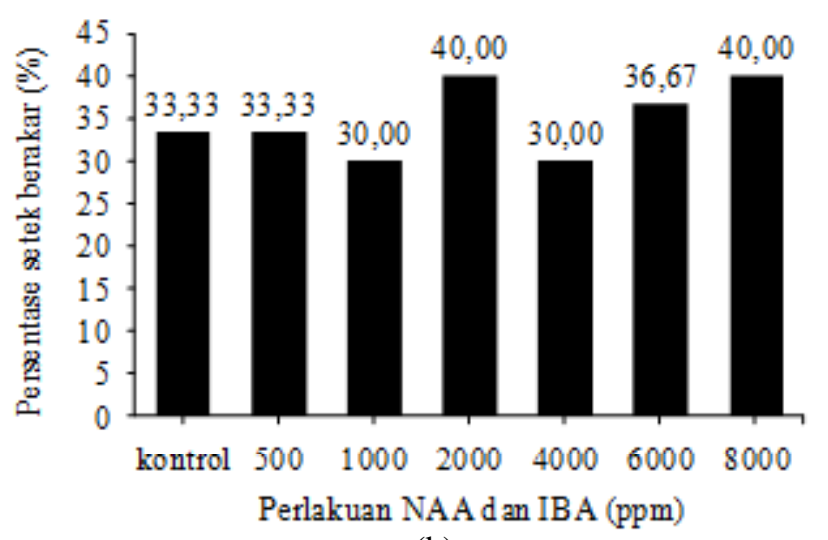

(b)

Gambar 1. Hubungan beberapa konsentrasi campuran NAA dan IBA dengan (a) persentase setek tumbuh dan (b) persentase setek berakar pada lada 2 bulan setelah penyetekan.

tanaman yang digunakan berumur 2 tahun. Menurut Balai Penelitian Tanaman Rempah dan Obat (1996) bahan tanaman yang dapat menghasilkan setek yang baik yaitu bahan setek yang didapat dari tanaman belum berproduksi dengan umur tanaman 6-9 bulan, pohon induk tanaman sedang dalam masa pertumbuhan tidak berbunga dan berbuah. Hal ini sesuai dengan Salisbury dan Ross (1995) yaitu setek yang berasal dari induk yang tua akan sulit berakar bila dibandingkan dengan bahan tanaman yang muda, karena bahan tanaman yang muda memiliki auksin.

Jika dilihat dari proporsi persentase akar yang terbentuk pada buku dan dasar setek, maka fenomena yang terjadi adalah semua setek pada perlakuan auksin maupun kontrol menghasilkan akar pada buku dengan persentase yang hampir sama. Namun, akar yang terbentuk di dasar setek hanya didapatkan pada setek dengan perlakuan auksin. Di samping itu, semakin tinggi konsentrasi auksin yang diberikan maka semakin tinggi persentase setek yang membentuk akar didasar setek. Hal ini diduga karena akar yang terbentuk di dasar setek merupakan akar yang terbentuk baru atau de novo roots dan pembentukan bakal akar jenis ini memerlukan ketersediaan auksin.

Menurut Hartmann et al. (2011) tanaman yang diregenerasikan dari setek batang, rizoma, umbi-umbian, dan struktur lain dapat membentuk akar adventif. Akar adventif adalah akar yang tumbuh dari bagian-bagian tanaman selain akar radikula. Akar adventif ada dua yaitu preformed roots dan wound-induced roots. Preformed roots adalah akar adventif yang sebelumnya sudah terbentuk pada buku-buku batang secara alami dan akar ini akan tumbuh ketika lingkungan di sekitarnya mendukung. Wound induced roots adalah akar pada batang atau dasar batang yang terbentuk setelah pelukaan misalnya pada potongan batang yang disetek. Akar ini terbentuk dari sel-sel tertentu di daerah sekitar potongan batang. Preformed roots muncul pada bagian buku tanaman sedangkan wound induced roots muncul pada bagian dasar setek batang. Persentase komposisi wound-induced root dan preformed roots pada pengakaran setek lada dua bulan setelah penyetekan dapat dilahat pada Gambar 2a.

Dilihat dari komposisinya, jenis akar yang terbentuk pada setek lada ternyata dipengaruhi oleh pemberian dan konsentrasi campuran auksin. Gambar 2a. Menunjukkan bahwa setek tanpa perlakuan campuran NAA dan IBA memiliki akar yang hanya berasal dari buku atau preformed roots. Perlakuan campuran NAA dan IBA mulai dengan konsentrasi 500 ppm dan 1000 ppm menghasilkan baik wound-induced root maupun preformed roots, walaupun persentase akar baru masih sangat sedikit. Persentase peningkatan akar pada dasar setek mengalami peningkatan pada konsentrasi 2000 ppm dan terus meningkat hingga 8000 ppm. Persentase akar pada dasar setek tertinggi terdapat pada perlakuan 8000 ppm yaitu $30 \%$.

Pengaruh campuran NAA dan IBA terhadap jumlah akar setek lada 2 bulan setelah penyetekan dapat dilihat pada Tabel 2. Hasil pengamatan jumlah akar primer menunjukkan pemberian perlakuan campuran NAA dan IBA berpengaruh nyata terhadap jumlah akar primer. Setek tanpa perlakuan campuran auksin NAA dan IBA menghasilkan akar primer paling sedikit yaitu 5 helai. Pemberian auksin campuran NAA dan IBA mulai dari 500 ppm hingga 8000 ppm secara signifikan meningkatkan jumlah akar primer dengan jumlah akar primer terbanyak terdapat pada perlakuan $500 \mathrm{ppm}$ dan 


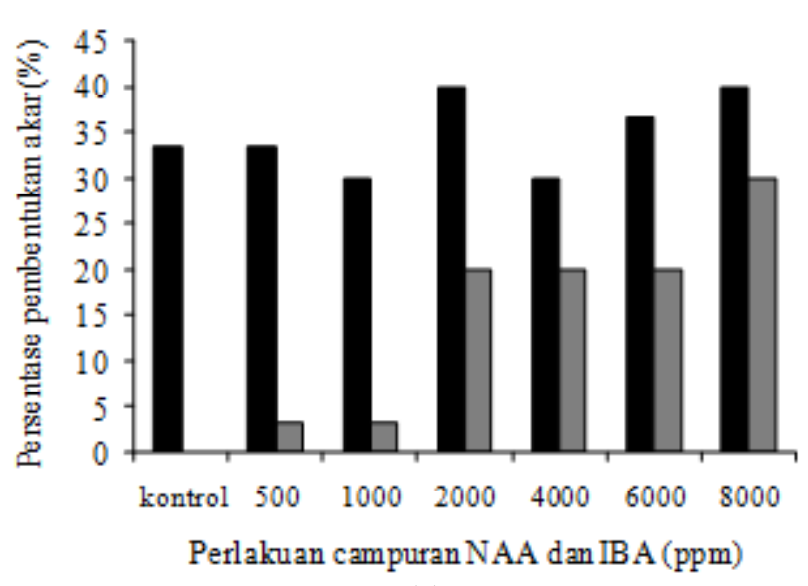

(a)

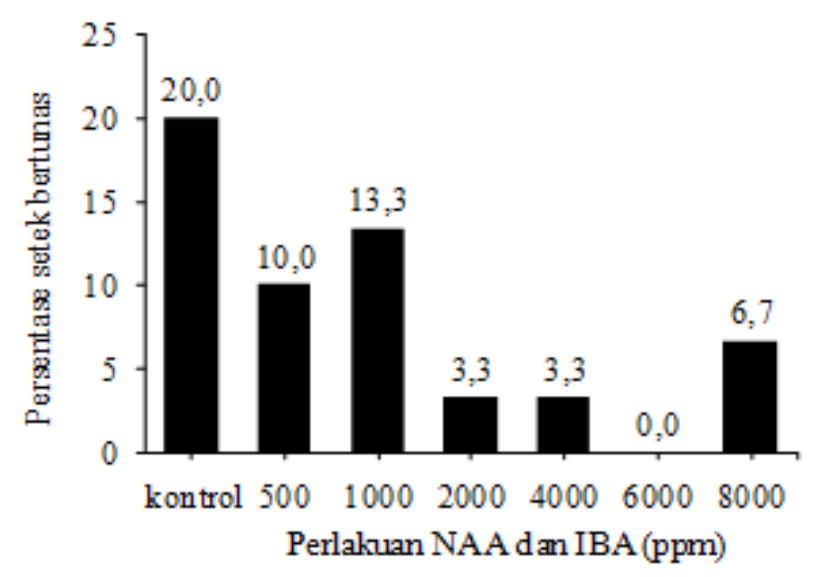

(b)

Gambar 2. Hubungan berbagai konsentrasi campuran auksin NAA dan IBA dengan (a) persentase setek berakar yang terbentuk dari buku dan dari dasar setek, (b) persentase setek bertunas pada lada 2 bulan setelah penyetekan.

Tabel 2. Pengaruh campuran NAA dan IBA terhadap jumlah akar setek lada 2 bulan setelah penyetekan.

\begin{tabular}{crll}
\hline $\begin{array}{c}\text { Perlakuan campu ran NAA } \\
\text { dan IBA }(\mathrm{p} \mathrm{pm})\end{array}$ & $\begin{array}{c}\text { Jumlah akar primer } \\
\text { (helai) }\end{array}$ & \multicolumn{1}{c}{ Keterangan } \\
\hline Kontrol & 5,0 & $\mathrm{~d}$ & $\begin{array}{l}\text { Akar berasal dari buku } \\
500\end{array}$ \\
1000 & 12,7 & $\mathrm{ab}$ & $\begin{array}{l}\text { Sebagian besar berasal dari buku } . \\
\text { Sebagian besar berasal dari buku. }\end{array}$ \\
2000 & 8,7 & $\mathrm{a}$ c & $\begin{array}{l}\text { Sebagian berasal dari buku dan sebagian } \\
\text { berasal dari dasar setek } \\
\text { Sebagian berasal dari buku dan sebagian } \\
\text { berasal dari dasar setek } \\
\text { Sebagian berasal dari buku dan sebagian } \\
\text { berasal dari dasar setek } \\
\text { Sebagian berasal dari buku dan sebagian bes ar } \\
\text { berasal dari dasar setek }\end{array}$ \\
\hline
\end{tabular}

BNT 0,05

3,03

Keterangan : Angka yang diikuti huruf yang sama tidak berbeda nyata berdasarkan uji BNT pada taraf 5\%.

1000 ppm. Di samping itu, terdapat kecendrungan bahwa akar yang terbentuk pada setek dengan perlakuan auksin yang lebih tinggi yaitu mulai dari 2000 ppm hingga 8000 ppm menghasilkan akar baru didasar setek selain akar dari buku.

Pengaruh campuran NAA dan IBA terhadap panjang akar primer setek lada 2 bulan setelah penyetekan dapat dilihat pada Tabel 3 . Hasil pengamatan panjang akar primer menunjukkan perlakuan campuran NAA dan IBA berpengaruh nyata terhadap rata-rata panjang akar primer. Pada perlakuan tanpa campuran NAA dan IBA menghasilkan akar primer paling pendek yaitu $5 \mathrm{~cm}$. Pemberian campuran NAA dan IBA mulai dari 500 ppm hingga 8000 ppm secara signifikan meningkatkan panjang akar primer dengan akar primer terpanjang terdapat pada perlakuan $6000 \mathrm{ppm}$.

Pengaruh campuran NAA dan IBA terhadap bobot basah akar setek lada 2 bulan setelah penyetekan dapat dilihat pada Tabel 3. Hasil pengamatan bobot segar akar menunjukkan bahwa perlakuan campuran NAA dan IBA berpengaruh nyata terhadap bobot segar akar primer. Setek lada tanpa perlakuan campuran NAA dan IBA atau kontrol dan perlakuan 500 ppm merupakan setek dengan bobot segar akar primer paling rendah yaitu $20 \mathrm{mg}$ dan $130 \mathrm{mg}$. Peningkatan campuran NAA dan IBA dari 4000 ppm menjadi 6000 ppm secara 
Tabel 3. Pengaruh campuran NAA dan IBA terhadap panjang akar primer setek lada 2 bulan setelah penyetekan.

Perlakuan campuran NAA dan $\quad$ Panjang akar primer $(\mathrm{cm}) \quad$ Bobot segar akar $(\mathrm{mg})$
IB A (ppm)

\begin{tabular}{crrrl}
\hline Kontrol & 0,63 & $\mathrm{c}$ & 20 & $\mathrm{~d}$ \\
500 & 3,07 & $\mathrm{~b}$ & 130 & $\mathrm{~d}$ \\
1000 & 3,63 & $\mathrm{~b}$ & 350 & $\mathrm{bcd}$ \\
2000 & 3,18 & $\mathrm{~b}$ & 250 & $\mathrm{~cd}$ \\
4000 & 4,26 & $\mathrm{~b}$ & 870 & $\mathrm{ab}$ \\
6000 & 6,0 & $\mathrm{a}$ & 1360 & $\mathrm{a}$ \\
8000 & 3,29 & $\mathrm{~b}$ & 750 & $\mathrm{bc}$ \\
\hline BNT 0,05 & \multicolumn{3}{c}{590} \\
\hline
\end{tabular}

Keterangan : Angka yang diikuti huruf yang sama tidak berbeda nyata berdasarkan uji BNT pada taraf 5\%.

meningkatkan bobot akar dari $870 \mathrm{mg}$ menjadi 1360 mg.

Hasil persentase setek bertunas menunjukkan bahwa setek tanpa perlakuan campuran NAA dan IBA atau kontrol memiliki peresentase jumlah tunas tertinggi yaitu $20 \%$ sedangkan perlakuan campuran NAA dan IBA dengan konsentrasi tinggi yaitu 6000 ppm menunjukkan setek belum bertunas (Gambar 2b). Menurut Stern et al. (2006) sulit untuk memprediksi respon sel terhadap auksin karena respon auksin berbeda-beda berdasarkan konsentrasi, lokasi dan lainlain. Apabila auksin dengan konsentrasi tertentu dapat merangsang tunas maka pada kondisi yang sama akan menghambat pengakaran. Jika auksin dengan konsentrasi tertentu dapat merangsang pengakaran, maka pada kondisi yang sama dapat menghambat perangsangan tunas. Hal ini sejalan dengan Sun dan Bassuk (1993) yaitu setek batang mawar dengan aplikasi IBA yang diberikan pada konsentrasi mulai 6000 ppm dapat menghambat pertumbuhan tunas.

Berdasarkan pengamatan visual yang dilakukan, setek lada dengan perlakuan 6000 ppm memiliki morfologi akar yang lebih baik bila dibandingkan dengan perlakuan lain. Perlakuan campuran NAA dan IBA 6000 ppm memiliki akar terpanjang dan nilai bobot basah akar terberat. Hal ini dapat dilihat dari Gambar 3 yang menunjukkan akar lada yang panjang dengan diameter akar lebih besar bila dibandingkan dengan perlakuan lain. Pemberian campuran auksin NAA dan IBA dapat meningkatkan pembentukan akar pada dasar setek. Akar pada dasar setek memiliki rambut akar lebih banyak bila dibandingkan dengan akar pada buku. Rambut akar berfungsi untuk menyerap air dan mineral dari dalam tanah, sehingga dengan pemberian campuran auksin NAA dan IBA dapat meningkatkan jumlah air, mineral dan unsur hara yang masuk ke dalam tanaman.
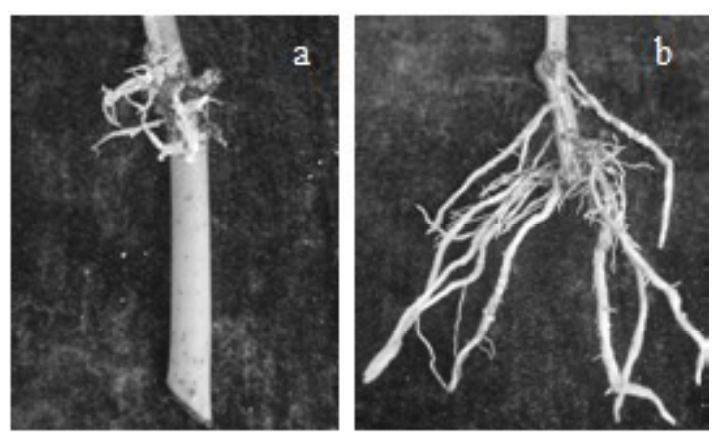

Gambar 3. Perakaran setek lada setelah 2 bulan dengan perlakuan konsentrasi campuran NAA dan IBA (a) 0 ppm dan (b) 6000 ppm.

Dengan demikian pemberian campuran auksin NAA dan IBA pada setek lada satu ruas akan menghasilkan bahan tanaman dengan kualitas yang baik dalam jumlah yang banyak.

\section{KESIMPULAN}

Hasil penelitian menunjukkan bahwa pemberian campuran NAA dan IBA mulai 500 ppm hingga 8000 ppm secara signifikan meningkatkan jumlah akar,, dengan jumlah akar terbanyak terdapat pada perlakuan 1000 ppm. Pemberian campuran NAA dan IBA mulai dari 500 ppm hingga 8000 ppm secara signifikan meningkatkan panjang akar primer dan bobot segar akar dengan akar terpanjang dan bobot akar tertinggi terdapat pada perlakuan $6000 \mathrm{ppm}$. Berdasarkan morfologi akar, panjang akar, dan bobot akar, pemberian campuran NAA dan IBA 6000 ppm merupakan perlakuan terbaik untuk merangsang pembentukan akar pada setek lada varietas Natar 1. Tanpa auksin setek lada tidak dapat membentuk 
akar di dasar setek. Aplikasi campuran auksin NAA dan IBA mulai dari 500 ppm hingga 8000 ppm merangsang pembentukan akar pada dasar setek dengan persentase tertinggi didapat pada perlakuan campuran NAA dan IBA 8000 ppm.

\section{DAFTAR PUSTAKA}

Akakpo, B. Daniel, A. Naalamle, Y. Julius, dan E. Blay. 2014. Effect of Indole 3-Butyric Acid and Media Type on Adventitious Root Formation in Shea nut Tree (Vittellaria paradoxa) Stem Cuttings. American Journal of Plant Science. 5:313-318.

Balai Informasi Pertanian Irian Jaya. 1994. Perbanyakan Tanaman Lada. http:// ebookily.org/pdf/perbanyakan-tanaman-ladapusat-perpustakaan-dan-91001233.html. Diakses pada tanggal : 28 Desember 2013.

Balai Penelitian Tanaman Rempah dan Obat. 1996. Monograf Tanaman Lada. Balitro. Bogor.

Hartmann, H. T., D. E. Kester., F. T. Davies, dan R. L. Geneve. 2011. Plant Propagation Principle and Practices. $8^{\text {th }}$ Edition. Upper Saddle River. New Jersey.
Lakitan, B. 1993. Dasar-Dasar Fisiologi Tumbuhan. Rajawali Press. Jakarta.

Noorunisa, M., A. Noman, B.A. Muhammad dan Q. Chachar. 2013. Influence Of Naphthalene Acetic Acid (NAA) On Sprouting And Rooting Potential Of Stem Cuttings Of Bougainvillea. Sci. Int. 25 (2): 299-304.

Paul, R. dan C. Aditi. 2009. IBA and NAA of 1000 ppm Induced more improved rooting characters in Air Layers of Waterapple (Syzygium javanica L.). Bulgarian Journal of Agricultural Science. 15 (2):123-128.

Pop I.T., P. Doru, dan C. Bellini. 2011. Auxin control in the formation of adventitious root. Not Bot Hort Agrobot Cluj. 39(1):307-316.

Salisbury, F.B dan C.W. Ross. 1995. Fisiologi Tumbuhan Jilid 3. Penerbit ITB. Bandung.

Sun, W.Q. dan N.L. Bassuk. 1993. Auxin induced ethylene synthesis during rooting and inhabitation of bud-break of 'Royalty' rose cutting. J. Amer. Soc. Hort. Sci. 118(5):638-643.

Stern, R.K., J.E. Bidlack, dan S.H. Jansky. 2006. Plant Biology. Higher Education. New York. 